\title{
[ 80$]$
}

XI. Obfervations on Mr. Peter Collinton's Paper on the Round Towers in Ireland, printed in the firft $V$ olume, p. 305. By Owen Salufbury Brereton, Efq. F. R.S.

Read at the Society of Antiluaries, Dec. 15, 1763.

THEN I lately made the tour of the fouth weft parts of Ireland, I faw feveral of thofe buildings called ufually Penitential Towers; not one of them had either belting or girting, nor the leaft fign of there having been any room in them till within ten feet of the top; that room had windows exactly facing the cardinal points; from thence, downward to the entrance, which is about fifteen feet above the furface of the ground, only a few flits were cut, juft to give light to perfons going up or down the ftairs. Thefe towers are all built of ftone, and exceeding itrong, the ftones and mortar remarkably good; and in general they are intire to this day, though many churches near which they ftood are either in ruins or totally deftroyed.

I $T$ H IN $\mathrm{K}$ them rather ancient Irih, than either Pictin or Danin ftructures, having never heard of one like them in Denmark, or any other part of Europe, except in Scotland: I faw one there at Abernethy, near Perth, which exactly refembles thofe in Ireland. Upon looking into Gordon's Itinerarium Septentrionale, I find his opinion is, that it was the work of the Picts: what reafon there is for fuch a conjecture I do not fee; I rather think we may conclude, when the Irih made their incurfiois into Scotland, they built the two towers there after the model of fo many they had left behind them in Iieland. However, I deem their antiquitygreatly 
$M r$. Salusbury Brereton, on the Irith Towers. $S_{t}$. to precede the ufe of bells, calt ones at leaft, in that country; and from their fituation near churches, and having a floor and windows only at the top, I verily believe their principal ufe to have been to receive a perfon to call the people to worfhip with fome wind inftrument, which would be heard from a much greater diftance than fmall uncaft bells poffibly could: One of thefe towers at Dramifkin is, at this day, made ufe of as a belfry. In Mahometan countries the voices of their Muezins, or callers to prayers, who ftand for that purpofe on turrets, much higher than their mofques, are heard to a very great diftance.

The Aegyptians at this day proclaim the time of worhip with fome wind inftrument from a high place; which I the rather take notice of here, becaufe the late Bifhop Pocock often mentions the amazing conformity he had obferved between the Irifh and the Aegyptians in many inftances.

WHEN in Holland, I was much furprized to what a diftance I beard the man, whofe ftation is at the top of their higheft. fteeples: he blows a trumpet frequently during the night, and if he obferves a fire, he keeps the inftrument directed that way, and blows with a continuance, which never fails to be heard to the moft diftant part of their largeft towns.

I MUST add here an anecdote I met with in a Welfh MS. of the Gwider family in North Wales, fince publifhed by my worthy friend $\mathrm{Mr}$. Barrington ; in which it appears, that fo late as the year I600, the common Welh were fo wild, that Sir John Wynn, when he went to church, was forced always to leave a watchman on an eminence, whence he could fee both his houfe and the chürch; his duty was, to give notice if he faw any attack made on the former, though it was always left bolted, barred, and guarded during church-time. This anecdote naturally hints another manife? ufe of thefe towers, as the caftles in Ireland (for fuch every ge:tleman's houfe was) almoft always ftood near a church ; and coneVOL. II. 
82 Mr. Salusbury Brereton, on the Irih Towers. quently in a country in that age ( 1015$)$ much more wild than Wales, a watchman at the top of one of thefe towers, remaining all church-time, muft be of the greateft advantage, to give alarms to the family in their churches.

I AM not fingular in my opinion on thefe matters, for both Earl Morton and Bihop Pocock concurred with me; the latter had feen a long trumpet of iron, which was dug from the bottom of one of thefe towers: feveral fuch have been found in Ireland, near thefe buildings; fome of them are exhibited in one of the plates publifhed by this Society, and others are now extant in the Royal Mufeum.

THE conjecture of their being for the reception of Penitents has been mentioned as Sir James Ware's opinion, but is, indeed, only that of Mr. Harris, the re-publifher of Sir James's Antiquities of Ireland: it is ingenious; and after bells came into ufe, thefe towers might be appropriated for fome fuch purpofe; but I cannot conceive it probable that the antient Irifh fhould build towers of fuch a height as 130 feet, for the fingle purpofe of having one room only, and that not five feet diameter, for Penitents : and the rather too, as the expence of building them muit have been immenfe; for the ftones in general muft have been brought from a very great diftance, and indeed, I thould think, the builders too, the workmanhip is fo good : whereas much fmaller places for prifons, on the ground, and of coarfer materials, would have anfwered every penitentiary ufe, infinitely better in every refpect, and the expence, in comparifon of thefe, would have be nn extremely trifling. 